\title{
Conversion of Khadrwai Dates from Khulal to Tamar through Various Practices
}

\author{
Rehman Ali*, Umber Shehzadi, Amara Rasheed, Maryam Bibi and \\ Anam Zafar \\ Institute of Home and Food Sciences, Government College University Faisalabad, \\ Pakistan
}

*Corresponding Author: Rehman Ali, Institute of Home and Food Sciences, Government College University, Faisalabad, Pakistan.
Received: July 20, 2020

Published: November 25, 2020

(C) All rights are reserved by Rehman Ali., et al.

\section{Abstract}

Dates have been an important basic food for several cultures all over the world and they are still consumed widely over thousands of year. The aim of our study was to protect khadrwai dates from monsoon season and minimize post-harvest losses. For this purpose, some bunches were wrapped with polythene plastic sheet, some covered in sacks and others remained open on date palm. Date samples were collected during Khalal, Rutab and Tamar stage by weekly intervals. Chemical and physical characteristics were determined using published procedures. Result showed firmness was more in polythene plastic dates about 4.733, 4.46 and 1.6 during every stage and other conditions have less firmness. Brix \% gradually increases during all stages. At full ripening stage, brix \% was near about 30 - 40\%. Color changes during ripening from light yellow at Khalal to golden brown at Rutab stage and then converted to dark brown color at Tamar stage. Moisture content was decrease with the passage of time. At Tamar stage, moisture content was about $15 \%$ which was beneficial for long term storage. The highest losses on date palm were observed in sack dates due to shrinkage of size and bitter taste. Monsoon season less effected on opened date palm. Polythene plastic condition is best for maximum production and minimum losses on date palm.

Keywords: Khudrwai Dates; Khalal Stage; Tamar Stage; Protection; Spoilage

\section{Introduction}

Pakistan is blessed with vast agriculture resources. In Pakistan date palm is an important cash crop. It is believed that dates were cultivated about 8000 years ago in Iraq. There are 200 varieties of dates like Ambera, Barhi, Deglet noor, Halawy, Hayani, Iteema, Kalmi, Khadrawy, Khola, Khudri, Khadrwai, Khola, Khudri, Mabroom, Maktoom, Medjool, Migraf, Safawi, Sukkari, Thoory, Warehouse and Zahidi [1]. Khudrawi Date is a single seed-ed berry with a pericarp and fabulous endocarp. Khadrwai dates are sweet and soft. They change color from orange brown to light brown with medium to broad oblong size. They are considered among the best dates both in texture and flavor. Mid-season khadrwai dates are ripe [2]. Dates Medjool is a healthy fruit. Most people find the dates to be dried fruit. The Medjool dates are usually picked, washed, sorted and packed from the date palm [3].
Depending on the sugar concentration i.e. sweetness, climate condition and market demands, the dates can be harvested at Khalal level [4]. Date fruit can be eaten at the Rutab stage but the fruit typically matures fully on the tree and is harvested at the Tamar stage. The climber must ascend unassisted to harvest the khudrwai dates, taking with him a rope that will support him when he reaches the top. Then bunches then cut down and lowered to the table. The dates are considered high-energy food with sugar and fiber, however, and are therefore good for people [5]. When the dates are left on the palm the will turn into Tamar stage at which they have the least amount of moisture and they are self-preserving $[6,7]$.

Khudrwai dates are eaten in various processed ways, fresh or dried. In the ripe stage ('Rutab' stage) they are also eaten freshly picked. This stage has a soft texture and is crisp to flavorful. Dates are consumed in some cultivars at the point of physiological matu- 
rity (the 'Khalal' stage). The stage in Khalal is colorful and crunchy. Many dates are eaten at a fully mature stage ('Tamar' stage). And flesh is dry in this stage. The date at this stage is distinguished by very low moisture content and is suitable to be consumed out of season for long-term storage. Losses occur at harvesting time [8].

Dates were a part of human diet having high levels of carbohydrates, minerals and vitamins, besides they also contain protein and fats are in small quantities. We have about 79.94g carbohydrates, $5 \%$ vitamin A, $10 \%$ niacin, $16 \%$ pantothenic acid and $19 \%$ pyridoxine, $11 \%$ iron, $13 \%$ manganese, $13 \%$ magnesium, $40 \%$ copper [9]. There is a relationship between sweetness and amount of sugar which increase gradually during maturation [5]. As both a staple and a dessert fruit they have great significance. They all are commonly eaten during the month of Ramadan. Consumption is also strong during Christmas time. The dates found their way into sweets, chocolates, bakery goods, preservatives, sauces and cereals for breakfast. Dates intake has many intestinal disorders, lets you gain weight, increases energy levels and enhances [10]. Dates possess important radical scavenging activity due to the presence of non-enzymatic antioxidants (phenolic, flavonoid and ascorbic acid) and enzymatic antioxidants (catalase, peroxidase and superoxide dismutase), compounds known to have health benefits $[11,12]$. Dates are created with various medicinally essential nutrients for the ailment of any disease. The khudrawi date palm has been known as the 'tree of life' because of its high amount of nutritional value and its long existence. Date fruit was found to be helpful in glycemic and lipid regulation of diabetic patients and was also reported as having antioxidant and anti-mutagenic properties [13].

Date characterizations based on various ways. The fruit flesh wright, flesh thickness and pit weight were used in physical characterization. Many of the studies have used chemical characterization to test their carbohydrates, minerals, vitamins and proteins. Firstly, it relies on physical properties which are then open to chemicals. The date's chemical and physical characteristics influenced their mechanical and rheological properties, which is a firmness and quality indicator. Features of size and shape are most commonly used in the sorting and sizing of dates [14].

To our knowledge, there is minor report on the khudrwai dates under different conditions for more growth. The goal of this research was to study the fruit quality properties of khudrwai dates at each stage of maturity affected by which condition. And deter- mine which condition is appropriate for use as a practical post-harvest treatment to improve its rate of production.

Pakistan is one of the main growers of dates. It follows Egypt, Saudi Arabia, Iran and U.A.E in the list of top date producing countries with $10 \%$ share of global production. Dates are grown in all four provinces of Pakistan. Important dates producing provinces are Sindh (Khairpur and Sukkur), Balochistan (Makran and Panjgoor), Khyber Pakhtunkhwa (D. I. Khan) and Punjab at Jhang, Muzafargarh, Bahawalpur and D. G. Khan [14].

Pakistan is an ideal place for date cultivations and productions of dates in Pakistan during the last 4 years are given in table 1 .

The area under cultivation and production in Punjab about last 4 years are given in table 2 .

\begin{tabular}{|l|c|c|}
\hline Year & Area (hectares) & Production (tons) \\
\hline $2014-2015$ & 91145 & 537204 \\
\hline $2015-2016$ & 97107 & 467756 \\
\hline $2016-2017$ & 60644 & 438989 \\
\hline $2017-2018$ & 98415 & 540606 \\
\hline
\end{tabular}

Table 1: Cultivation and production of date fruits in Pakistan.

\begin{tabular}{|l|c|c|}
\hline Year & Area (hectares) & Production (tons) \\
\hline $2014-2015$ & 5781 & 44041 \\
\hline $2015-2016$ & 5783 & 42931 \\
\hline $2016-2017$ & 5776 & 43548 \\
\hline $2017-2018$ & 4930 & 37792 \\
\hline
\end{tabular}

Table 2: Cultivation and production of date fruits in Punjab.

Source: Government of Pakistan, Ministry of Food, Agriculture and Livestock, Islamabad.

\section{Materials and Methods}

Date samples

The experiments were performed by collecting Khudrwai dates samples in three conditions (open, polythene plastic sheets and sacks) at three separate maturity stages (Rutab, Khalal and Tamar) to characterize the rainy season ripening process and rate of production from Agriculture Ayub Research Faisalabad. Some of the sampling dates were sorted, cleaned for physical and chemical analysis, at each maturation stage. Then each sample was packed in plastic polystyrene box and stored at temperature of $25^{\circ} \mathrm{C}$ and humidity of 75 percent. 


\section{Chemical and physical analysis of date samples}

Moisture content, firmness, color and brix were analyzed at different stages of all three types of khudrwai dates at $25^{\circ} \mathrm{C}$ storage.

\section{Weight loss}

At each stage the Khudrwai dates of each condition were used for measurement. The dates were separately taken to the laboratory and weighed by a weighing balance, one by one. The findings reported have been expressed as a percentage of weight loss over initial value [5].

\section{Moisture content}

Samples were analyzed for moisture according to AOAC method. This method depends on measuring the mass of water in a known mass of sample before and after the water. $5 \mathrm{~g}$ of each sample drying in an oven at $105^{\circ} \mathrm{C}$ for at least $18 \mathrm{hrs}$.

Where $\mathrm{W} 1$ = Weight $(\mathrm{g})$ of sample before drying and $\mathrm{W} 2=$ Weight ( $g$ ) of sample after drying. To achieve an exact calculation of the moisture content, all water molecules initially contained in the product must be separated without altering the mass of the date samples $[13,15]$.

\section{Firmness}

A texture analyzer was used to determine firmness. Comparably, thicknesses were taken two readings per khudrwai condition. Check firmness at room temperature of about $25^{\circ} \mathrm{C}$ with cylindrical puncture probe with a diameter of $7 \mathrm{~mm}$. The probe's passing speed and all test puncture depth were $0.2 \mathrm{~mm} / \mathrm{sec}$ and $2 \mathrm{~mm}$ respectively. Maximum force was reported as indication of firmness during the punching process [16].

Total soluble solids (Brix \%)

Date flesh of each condition was taken at each point of the Khala, Rutab, and Tamar and grinded by pestle in a mortar at room temperature of $25^{\circ} \mathrm{C}$. Juice was obtained by pressing muslin cloth over the pulp. For the determination of TSS a hand refractometer has been used. A drop of solution was poured into the inner face of the refractometer cover and firmly presses the cover against the glass prism. Then, the percentage of solid was read. Result were expressed as percent of total soluble solid (Brix \%) in juice at $25^{\circ} \mathrm{C}$ [5].

\section{Color}

The color of date samples was evaluated using a modified meth- od. Pictures of the date samples were taken in a fully closed white cardboard box using a digital camera. During photography the option flash was kept off. The gap from camera to box bottom was $30 \mathrm{~cm}$. For all samples the relative location of the camera and the sample is kept the same. Color was calculated inside the software's "Lab" mode. The color measurement tests were performed in triplicate [16].

\section{Results and Discussion}

Dates of khudrwai variety at each maturity stage were treated. The treatments were performed on date palm by applying different conditions (Opened, wrapped in polythene plastic sheets and in sacks) on the dates. Different tests were also performed for physical and chemical analysis after harvesting at each maturity stage to determine which condition was good for high productivity.

\section{Weight loss}

Samples of khudrwai dates at different conditions on each maturity stage were observed. For determination the quantity of dates, weighing balance was used. Open dates at Khalal stage was $55 \mathrm{~kg}$ and after conversion into Tamar stage the weight was $45 \mathrm{~kg}$. Therefore, during conversion, the observed total weight loss was $10 \mathrm{~kg}$ which was about $19 \%$. In open condition dates take much time to become ripe to convert from Khalal to Tamar stage. They were maximum in number and thin in size as compared to others polythene plastic dates and bag dates. Weight of polythene plastic sheeted dates at Khalal stage was $21 \mathrm{~kg}$ and at Tamar stage was 19 $\mathrm{kg}$. Weight loss with polythene plastic sheet was $10 \%$. A significant difference was observed that Polythene dates were ripen frequently and $90 \%$ Tamar dates were produced. Like open dates they were also thin in size. Tamar stage is a fully ripened stage and at this stage weight loss was controlled. In sack, weight of dates at Khalal stage was $9 \mathrm{~kg}$ and after the conversion into Tamar stage weight was $3 \mathrm{~kg}$. Observed weight losses were $6.66 \%$ and produce $33.3 \%$ of Tamar dates. The result regarding weight losses are in table 3. They were very thick in size. Figure 1 shows the percentage of gain and loss of khudrwai during conversion of Khalal stage to Tamar stage by applying (Opened, wrapped in polythene plastic sheets and in sacks) conditions. In sack, maximum production losses were observed due to improper respiration process. Weight loss is a physiological event caused by loss of water from the fruit surface to the surrounding atmosphere and loss of carbon on formation of $\mathrm{CO}_{2}$ during respiration [17]. 


\begin{tabular}{|l|c|c|c|c|}
\hline Date Palm Conditions & Weight at Khalal stage (kg) & Weight at Tamar stage (kg) & Loss (kg) & \% weight losses (\%) \\
\hline Opened & 55 & 45 & 10 & 19 \\
\hline Polythene plastic sheeted & 21 & 19 & 2 & 10 \\
\hline sacked & 9 & 3 & 6 & 66.6 \\
\hline
\end{tabular}

Table 3: Weight loss of date fruit during different condition on date palm.

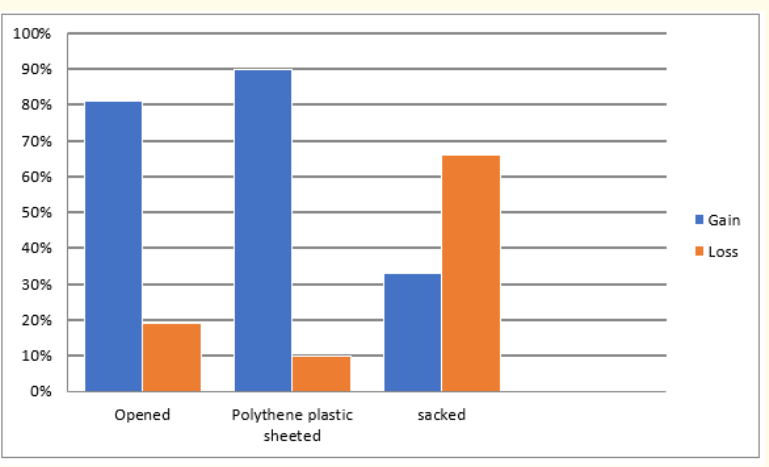

Figure 1: The percentage of gain and loss of khudrwai during conversion of Khalal stage to Tamar stage by applying various conditions.

\section{Moisture content}

Moisture is a good parameter for food spoilage and acceptability, the moisture content of the three stages of dates (Khalal, Rutab, Tamar) in different conditions were investigated. In open dates, at Khalal stage moisture content is $54 \%$. At Rutab stage $33 \%$ and at Tamar stage $15 \%$. In polythene plastic dates moisture was $57 \%$ at Khalal stage and at Rutab stage it was 35\%. At Tamar stage moisture was $14 \%$ in polythene plastic conditioned dates. In sack dates moisture content was $51 \%$ at Khalal stage. At Rutab and Tamar stage it was $32 \%$ and $16 \%$ in sack dates respectively. The results regarding moisture content are in table 4 . From Khalal to Rutab stage moisture content was decrease. At this stage the dates will be non-perishable and can be store for longer period of time and can also be prevented from microbial attack yeast and mold. The high moisture content will facilitate spoilage of dates and low moisture content will leads to dry dates and they are not acceptable to consumer. Moisture content is dependent upon climate conditions, harvesting period and drying conditions $[5,18]$.

\begin{tabular}{|l|c|c|c|}
\hline Date Palm conditions & Khalal & Rutab & Tamar \\
\hline Opened & 54 & 33 & 15 \\
\hline Polythene plastic sheeted & 57 & 35 & 14 \\
\hline Sacked & 51 & 32 & 16 \\
\hline
\end{tabular}

Table 4: Moisture content of date fruit during different condition on date palm.

\section{Firmness}

Firmness is one the main quality parameter in sensory acceptance of the date's fruits by the consumer. Texture Analyzer instrument was used for the evaluation of texture quantitatively. Firmness is calculated as maximum force required form the texture test (N). In open dates initial firmness was $3.81 \mathrm{~N}$ in khudrwai dates at Khalal stage. At Rutab and Tamar stage firmness was $4.24 \mathrm{~N}$ and $1 \mathrm{~N}$ respectively. Khalal fruits that lost their hard and crisp texture have lower quality and price. In polythene plastic sheeted date's firmness was $4.73 \mathrm{~N}$ at Khalal stage. At Rutab and Tamar stage firmness was $4.46 \mathrm{~N}$ and $1.6 \mathrm{~N}$ respectively. At Khalal stage of sack dates, firmness was $4.37 \mathrm{~N}$. At Rutab stage firmness was $5.14 \mathrm{~N}$ and at Tamar stage was $0.9 \mathrm{~N}$ in sack dates. The result regarding firmness are in table 5. Firmness loss could also be linked to the action of softening promoting enzyme such as polygalacturonase [19]. The higher water temperature caused disturbance in cell structure and membrane damage in fruit samples which was the source of decrease in fruit firmness [17].

\begin{tabular}{|l|c|c|c|}
\hline Date Palm conditions & Khalal & Rutab & Tamar \\
\hline Opened & 3.81 & 4.24 & 1 \\
\hline Polythene plastic sheeted & 4.73 & 4.46 & 1.6 \\
\hline Sacked & 4.37 & 3.14 & 0.9 \\
\hline
\end{tabular}

Table 5: Firmness of date fruit during different condition on date palm.

Brix

Brix (total soluble sugars TSS) were measured using refractometer. TSS is the main quality factors effecting taste and flavor. In open dates at Khalal stage $17.9 \%$ brix was observed. At Rutab and Tamar stage brix was $23.1 \%$ and $35.3 \%$ respectively. In polythene plastic sheeted dates, brix was $16.3 \%$ at Khalal stage. Then dates are changed into Tamar stage from Rutab stage. At Rutab stage brix was $23.4 \%$ and at Tamar stage brix was $41.7 \%$. In sack dates at Khalal stage brix was $14 \%$. At Rutab stage, brix was $23.4 \%$ and at Tamar stage brix was $31.5 \%$ The result regarding brix are in table 6. Result shows that TTS\% increase progressively towards Tamar stage. Date ripening was in associated with an increase in total fruit soluble solids, which appears linked in increase to cell wall hydrolyzing enzyme during ripening. However, decline in moisture con- 
tent and increase in sugar contents renders date extremely resistant to fungal spoilage after harvest. That's why, polythene plastic wrapped date showed much better result and increase shelf life. From the polythene dates were protected from the monsoon, Moisture and sugar content all were in controlled condition [18].

\begin{tabular}{|l|c|c|c|}
\hline Date Palm conditions & Khalal & Rutab & Tamar \\
\hline Opened & 17.9 & 23.1 & 35.3 \\
\hline Polythene plastic sheeted & 16.3 & 23.4 & 41.7 \\
\hline Sacked & 14.0 & 23.4 & 31.5 \\
\hline
\end{tabular}

Table 6: Brix of date fruit during different condition on date palm.

Color

The color of date plays vital role in the marketing value and quality index. Color variations were related to ripening process. The color of open khudrwai dates was observed. At initial stage (Khalal stage) the color was light yellow and at Rutab stage color was golden brown of open dates. After weekly interval at Tamar stage the color becomes dark brown. Polythene plastic sheet dates have light yellow color at Khalal stage and at Rutab stage golden brown color appears. At Tamar stage dark brown color was observed. In sack dates, color changes were also observed. At Khalal stage the color was light yellow and at Rutab and Tamar stage it turns into golden brown and dark brown color respectively. The result regarding color are in table 7 . At elevated temperature, the main factors responsible for the darkening of dates are oxidative browning of phenolic compounds and sugar browning [16].

\begin{tabular}{|l|c|c|c|}
\hline $\begin{array}{l}\text { Date Palm condi- } \\
\text { tions }\end{array}$ & Khalal & Rutab & Tamar \\
\hline Opened & Light yellow & Golden brown & Dark brown \\
\hline $\begin{array}{l}\text { Polythene plastic } \\
\text { sheeted }\end{array}$ & Light yellow & Golden brown & Dark brown \\
\hline Sacked & Light yellow & Golden brown & Dark brown \\
\hline
\end{tabular}

Table 7: Color of date fruit during different condition on date palm.

\section{Conclusion}

The existing study revealed that the khudrwai dates in polythene plastic condition on date palm is best for maintaining production and quality rate. This condition showed result at each maturity stage (Khalal, Rutab and Tamar), involves weight losses, TSS, moisture content, color and firmness according to the demands. While the interaction of opened and sack dates decrease the production rate and increase the losses rate. These losses might be due to monsoon. Khudrwai dates of Polythene plastic sheet have thin size and good taste while on the other hand opened and sacks dates have reduction in size with the passage of time and have bitter taste. Due to the shrinkage of size more weight losses occur. It is especially important to developed polythene plastic condition during development of stages for best quality; minimize postharvest losses and protection against monsoon.

\section{Bibliography}

1. Muhammad N., et al. "Quality evaluation of some Pakistani date varieties". Pakistan Journal of Agricultural Sciences 48.4 (2011): 305-313.

2. Mahawar MK., et al. "Determination of some physical properties of date palm fruits (cv. Khadrawy and medjool)” (2017).

3. Khallouki F., et al. "Characterization of phenolic compounds in mature Moroccan Medjool date palm fruits (Phoenix dactylifera) by HPLC-DAD-ESI-MS". Journal of Food Composition and Analysis 70 (2018): 63-71.

4. Al-Enezi NA and JM Al-Khayri. "Alterations of DNA, ions and photosynthetic pigments content in date palm seedlings induced by X-irradiation". International Journal of Agriculture and Biology 14.3 (2012).

5. Tafti AG and M Fooladi. "A study on the physico-chemical properties of Iranian Shamsaei date at different stages of maturity". World Journal of Dairy and Food Sciences 1.1 (2006): 28-32.

6. Myhara RM., et al. "Sensory and textural changes in maturing Omani dates". Journal of the Science of Food and Agriculture 80.15 (2000): 2181-2185.

7. Tafti AG and M Fooladi. "Changes in physical and chemical characteristics of Mozafati date fruit during development". Journal of Biological Sciences 3 (2005): 319-322.

8. Yahia EM and A Kader. "Date (Phoenix dactylifera L.), in Postharvest biology and technology of tropical and subtropical fruits (2011): 41-81.

9. Alghamdi AA., et al. "Nutritional assessment of different date fruits (Phoenix dactylifera L.) varieties cultivated in Hail province, Saudi Arabia". Bioscience Biotechnology Research Communication 11.2 (2018): 263-269.

10. Ali A., et al. "Nutritional and Medicinal Value of Date Fruit". Dates: Production, Processing, Food, and Medicinal Values 50 (2012): 361. 
11. Biglari F., et al. "Antioxidant activity and phenolic content of various date palm (Phoenix dactylifera) fruits from Iran". Food Chemistry 107.4 (2008): 1636-1641.

12. Awad MA., et al. "Antioxidant capacity, antioxidant compounds and antioxidant enzyme activities in five date cultivars during development and ripening". Scientia Horticulturae 129.4 (2011): 688-693.

13. Parvin S., et al. "Nutritional analysis of date fruits (Phoenix dactylifera L.) in perspective of Bangladesh". American Journal of Life Sciences 3.4 (2015): 274-278.

14. Markhand GS., et al. "Fruit characterization of Pakistani dates". Pakistan Journal of Botany 42.6 (2010): 3715-3722.

15. Singh V., et al. "Instrumental texture profile analysis (TPA) of date fruits as a function of its physico-chemical properties". Industrial Crops and Products 50 (2013): 866-873.

16. Farahnaky A., et al. "Accelerated ripening of Kabkab dates using sodium chloride and acetic acid solutions". Iran Agricultural Research 27.1-2 (2010): 99-112.

17. Mortazavi S., et al. "Interactive effects of temperature and 1-methylcyclopropene on 'barhee' date fruit quality picked at khalal stage". In IV International Date Palm Conference 882 (2010).

18. Rastegar S., et al. "Enzyme activity and biochemical changes of three date palm cultivars with different softening pattern during ripening". Food Chemistry 134.3 (2012): 1279-1286.

\section{Assets from publication with us}

- Prompt Acknowledgement after receiving the article

- Thorough Double blinded peer review

- Rapid Publication

- Issue of Publication Certificate

- High visibility of your Published work

Website: www.actascientific.com/

Submit Article: www.actascientific.com/submission.php

Email us: editor@actascientific.com

Contact us: +919182824667 